Document downloaded from:

http://hdl.handle.net/10251/50006

This paper must be cited as:

Corbatón Báguena, MJ.; Alvarez Blanco, S.; Vincent Vela, MC. (2014). Salt cleaning of ultrafiltration membranes fouled by whey model solutions. Separation and Purification Technology. 132:226-233. doi:10.1016/j.seppur.2014.05.029.

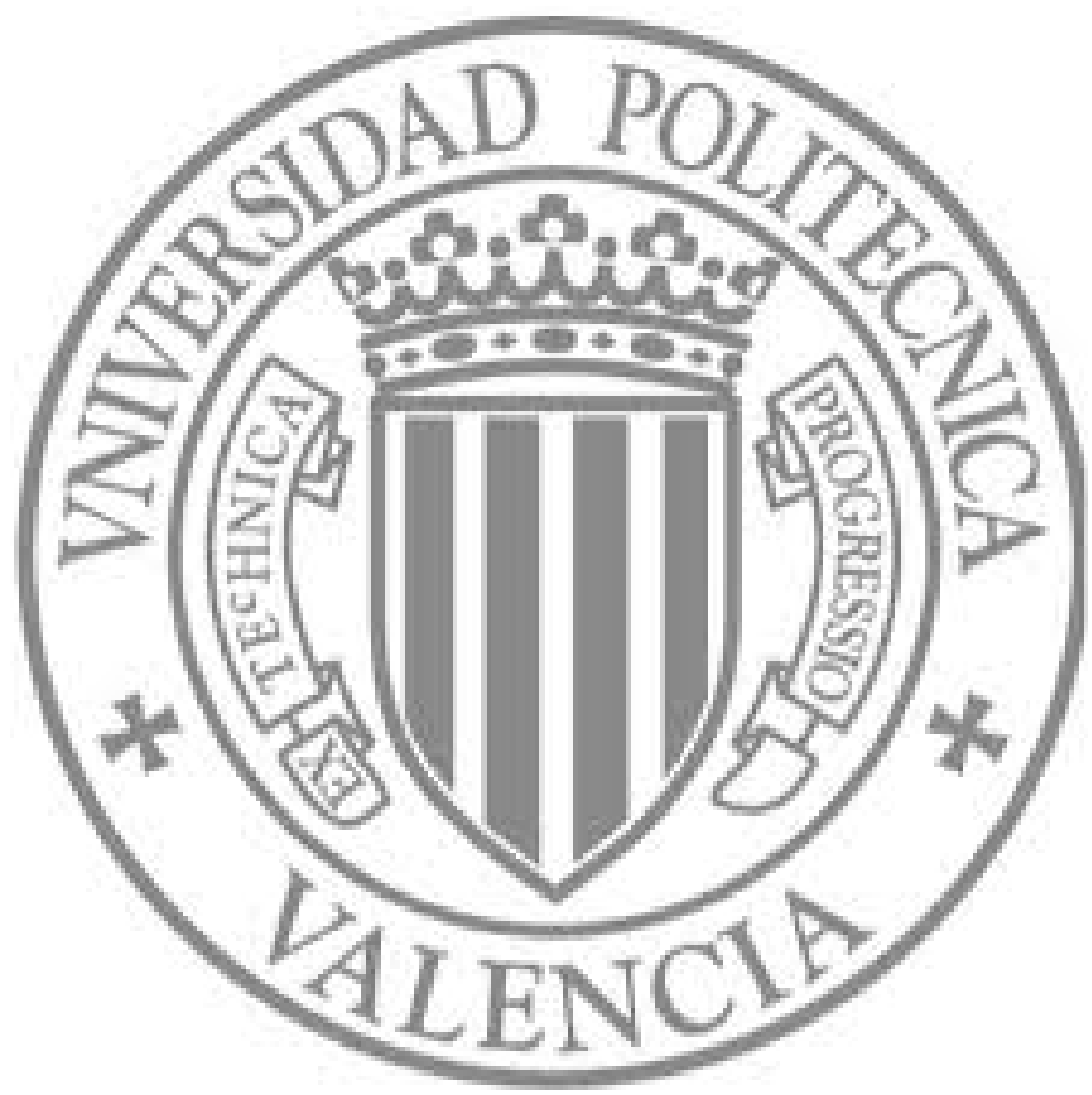

The final publication is available at

http://dx.doi.org/10.1016/j.seppur.2014.05.029

Copyright Elsevier 


\section{Salt cleaning of ultrafiltration membranes fouled by whey model} solutions

Department of Chemical and Nuclear Engineering, Universitat Politècnica de València,

9 *Corresponding author: sialvare@iqn.upv.es

10 Tel: +34963877000 (Ext.: 76383)

11 Fax: +34963877639 (Ext.: 77639)

\section{Abstract}

In this work, three ultrafiltration (UF) membranes were fouled with whey model solutions that contained BSA $(1 \% \mathrm{w} / \mathrm{w})$ and $\mathrm{CaCl}_{2}(0.06 \% \mathrm{w} / \mathrm{w})$. These membranes were cleaned with $\mathrm{NaCl}$ solutions. Temperature, crossflow velocity and concentration were varied. The membranes considered were a polyethersulfone (PES) membrane, a ceramic $\mathrm{ZrO}_{2}-\mathrm{TiO}_{2}$ membrane and a permanently hydrophilic polyethersulfone (PESH) membrane. Their molecular weight cut-offs (MWCOs) are 5, 15 and $30 \mathrm{kDa}$, respectively. The cleaning

21 efficiency was related to the MWCO, membrane material and operating conditions. The results obtained demonstrated that $\mathrm{NaCl}$ solutions were able to clean the membranes tested.

23 In addition, the higher the temperature and the crossflow velocity of the cleaning solution,

24 the higher the cleaning efficiency was. However, there was an optimum value of $\mathrm{NaCl}$ concentration to clean the membranes effectively. When concentration was higher than the 
optimum, the cleaning efficiency decreased. The relationship between the cleaning

27 efficiency and the operating conditions was obtained with statistical and optimization analysis.

Keywords: Ultrafiltration; whey model solutions; $\mathrm{NaCl}$ solutions; membrane cleaning

\section{Introduction}

34 In dairy industries, ultrafiltration (UF) is one of the most widely used membrane separation processes. Its most important applications are milk dehydration, whey concentration and protein fractionation or purification $[1,2]$. However, the major drawback in the application of UF processes is the progressive flux decline due to the fouling phenomena. In the dairy industry, membrane fouling is mainly caused by protein deposition on the membrane surface and adsorption inside its porous structure [3]. To minimize membrane fouling, several authors have investigated protein-protein, protein-membrane and also, protein-

41 inorganic compounds interactions [3, 4, 5]. Almécija et al. [3] studied the influence of 42 calcium salts on the UF of whey using a $50 \mathrm{kDa}$ ceramic membrane. They demonstrated that these salts can act as binding agents between proteins. When the concentration of

44 calcium salts increased, the percentage of membrane blocked pores during UF increased while the permeate flux through the membrane decreased. Ang and Elimelech [4] studied 46 the effect of calcium concentration on the bovine serum albumin (BSA) fouling of reverse 47 osmosis membranes. They reported that permeate flux decline was greater when calcium concentration increased, due to the reduction of the electrostatic repulsion among BSA molecules. Mo et al. [5] studied the effect of several cations and ionic strength on BSA fouling on reverse osmosis membranes. Calcium cations acted as crosslinking agents with 
51 BSA molecules. Fouling experiments demonstrated that BSA fouling rate increased when

52 calcium was present in the feed solution. Fouling rate also increased as ionic strength of 53 the feed solution increased.

To overcome membrane fouling, membranes have to be cleaned to remove the deposits. In dairy industries, chemical cleaning procedures are carried out even twice a day [6]. The conventional procedure to clean membranes fouled with whey solutions consists of several steps of alkali, acid and disinfectant washings [1, 2, 3, 7]. However, membranes may be damaged by these cleaning agents, reducing the membrane lifetime and causing a negative

60 impact on the environment when they are discharged as wastewaters. Therefore, alternative

61 cleaning techniques have been developed in the last years such as electromagnetic fields

62 [8], ultrasounds [9] and saline solutions. Several authors [10-12] have investigated the effect of salts on protein-protein interactions. Tsumoto et al. [10] studied the effect of several salts on protein-protein interactions. They observed that, at the same concentration, some salts (such as $\mathrm{Na}_{2} \mathrm{SO}_{4}$ ) caused a decline in protein solubility while other salts (such as

$66 \mathrm{NaCl}$ ) increased the solubility of proteins. The effect of salts that decreased protein

67 solubility is known as salting-out effect. On the other hand, the effect of increasing protein solubility is known as salting-in effect. Zhang [11] reported that $\mathrm{Cl}^{-}$was able to

69 specifically bind to the proteins surface more strongly than other cations and anions. Thus,

70 the repulsive intermolecular interactions increase and protein solubility also increases.

71 Hofmeister [12] proposed a ranking of the capability of several cations and anions to salt-

72 out or salt-in proteins. Based on the Hofmeister series, Nucci and Vanderkooi [13] reported

73 a series of divalent and monovalent cations and classified them in order of their ability to

74 precipitate proteins. According to these series, calcium cation is one of the most salting-out 
ions, which is in agreement with other works about the effect of calcium on protein fouling $[3,4]$.

However, only a few papers investigated membrane cleaning by means of saline solutions $[14,15]$. Lee and Elimelech [14] cleaned reverse osmosis membranes fouled with alginate and calcium solutions with $\mathrm{NaCl}$ aqueous solutions at different concentrations. Their results showed that cleaning efficiencies of about $90 \%$ were achieved with $\mathrm{NaCl}$ solutions of $50 \mathrm{mM}$. However, increasing $\mathrm{NaCl}$ concentration from 50 to $300 \mathrm{mM}$ did not cause an increase in the cleaning efficiency. In a previous work, Corbatón-Báguena et al. [15] cleaned a $15 \mathrm{kDa}$ MWCO UF membrane fouled with BSA solutions with different saline solutions $\left(\mathrm{Na}_{2} \mathrm{SO}_{4}, \mathrm{NaCl}, \mathrm{NaNO}_{3}, \mathrm{NH}_{4} \mathrm{Cl}\right.$ and $\left.\mathrm{KCl}\right)$. The highest values of hydraulic cleaning efficiency $(\mathrm{HCE})$ were obtained with $\mathrm{NaCl}, \mathrm{NaNO}_{3}, \mathrm{NH}_{4} \mathrm{Cl}$ and $\mathrm{KCl}$ solutions.

The aim of this work is to evaluate the ability of $\mathrm{NaCl}$ solutions to clean a monotubular ceramic UF membrane of $15 \mathrm{kDa}$ and two flat-sheet polymeric UF membranes of 5 and 30 $\mathrm{kDa}$ fouled by whey model solutions. The solutions consisted of BSA $1 \%(\mathrm{w} / \mathrm{w})$ and $\mathrm{CaCl}_{2}(0.06 \%(\mathrm{w} / \mathrm{w})$ in calcium). The influence of the operating conditions (temperature, crossflow velocity and $\mathrm{NaCl}$ concentration of the cleaning solution), membrane material and molecular weight cut-off (MWCO) on the membrane cleaning efficiency was investigated. In order to determine the optimal values of the cleaning operating conditions to achieve the highest cleaning efficiency, statistical and optimization analysis were performed.

\section{Materials and methods}


102 Fouling experiments were performed using aqueous solutions that contained BSA (1\% $103(\mathrm{w} / \mathrm{w}))$ and $\mathrm{CaCl}_{2}(0.06 \%(\mathrm{w} / \mathrm{w})$ in calcium) as feed solutions. BSA (prepared by heat 104 shock fractionation, lyophilized powder, $98 \%$ purity, A3733, Sigma-Aldrich, Germany) 105 and $\mathrm{CaCl}_{2}$ (95\% purity, Panreac, Spain) were dissolved in deionized water until the above 106 mentioned concentration was achieved. Isoelectric point of BSA is 4.9, according to the 107 manufacturer. Feed solutions had a $\mathrm{pH}$ of about 7, thus BSA has mainly negative net

108 charge on its surface. Its configuration is elliptic $(11.6 \times 2.7 \times 2.7 \mathrm{~nm})$ and it is one of the 109 most widely used whey proteins to prepare model solutions for UF experiments $[15,16$,

$11017,18] . \mathrm{CaCl}_{2}$ is one of the most often used salts to study the interactions between whey 111 proteins and salts $[3,4,5]$.

113 Membranes were cleaned with $\mathrm{NaCl}$ aqueous solutions (121659, Panreac, Spain) at a pH 114 ranging from 6.8 to $7 . \mathrm{NaOH}$ aqueous solutions (211687, Panreac, Spain) and $\mathrm{NaClO}$ 115 aqueous solutions (211921, Panreac, Spain) at a pH 11 were used as alkaline cleaning 116 agents.

\subsection{Membranes}

120 The membranes used in the experiments were: a flat sheet polyethersulfone (PES) 121 membrane of $5 \mathrm{kDa}$ (reference UP005), a flat sheet permanentely hydrophilic 122 polyethersulfone (PESH) membrane of $30 \mathrm{kDa}$ (reference UH030) and a monotubular ceramic membrane of $15 \mathrm{kDa}$. The polymeric membranes were supplied by Microdyn-

124 Nadir, Germany. They had an effective area of $100 \mathrm{~cm}^{2}$. The ceramic membrane was 
125 supplied by TAMI Industries, France. It consisted of a $\mathrm{TiO}_{2}$ support layer and a $\mathrm{ZrO}_{2}-\mathrm{TiO}_{2}$

126 active layer and its effective area was $35.5 \mathrm{~cm}^{2}$. It was $20 \mathrm{~cm}$ long with an internal

127 diameter of $0.6 \mathrm{~cm}$ and an external diameter of $1 \mathrm{~cm}$. The properties of these membranes

128 are shown in Table 1. These membranes were selected for this study because their MWCO

129 was lower than the molecular weight of BSA $(67 \mathrm{kDa})$. This fact ensured high BSA

130 rejection values. Moreover, they have MWCOs within the typical range for the production

131 of whey protein concentrates. In addition, high thermal stability was desirable because high

132 temperatures favour membrane cleaning. According to Table 1, this characteristic was

133 common to all the membranes tested. Three different MWCOs (5, 15 and $30 \mathrm{kDa})$ and

134 different membrane materials (PES, $\mathrm{ZrO}_{2}-\mathrm{TiO}_{2}$ and $\mathrm{PESH}$ ) were selected to investigate

135 their influence on the cleaning efficiency.

136

137

\subsection{Experimental set-up}

138

139 A VF-S11 UF plant (supplied by Orelis, France) was used to perform the fouling and

140 cleaning experiments. It consisted of a 10 L stainless steel feed tank, a variable speed

141 volumetric pump to control de crossflow velocity of each step, two manometers to measure

142 the pressure drop across the membrane module, a temperature regulating system and a

143 scale (0.001 g accuracy) to gravimetrically determine the permeate flux. This experimental

144 set-up was described elsewhere [15].

145

146 All the experiments were performed in total recirculation mode, except in the case of the

147 rinsing step. Operating conditions during the fouling experiments were a transmembrane

148 pressure of 2 bar, a crossflow velocity of $2 \mathrm{~m} \cdot \mathrm{s}^{-1}$ and a temperature of $25^{\circ} \mathrm{C}$. The duration 
149 of the tests was $3 \mathrm{~h}$. These experimental conditions were selected according to previous

150 studies on whey and protein ultrafiltration $[15,19]$.

151

2.4. Experimental procedure

153

154

2.4.1. Fouling experiments

155

156 Permeate flux, hydraulic resistance and rejection were measured during the fouling process

157 to ensure that the values obtained were reproducible in all runs. Each fouling experiment

158 was repeated a minimum of 10 times.

159

160 BSA rejection coefficient (Eq. 1) was calculated by measuring the permeate BSA 161 concentration during the fouling tests. Measurements were performed by an UV-visible 162 spectrophotometer (Hewlett-Packard 8453) at the wavelength corresponding with the 163 maximum of BSA absorbance $(278 \mathrm{mn})$.

164

165

$$
\text { Rejection }(\%)=\left(1-\frac{C_{p}}{C_{b}}\right) \cdot 100
$$

167 In Eq. $1 C_{b}$ is the BSA concentration in the feed solution $(1 \%(\mathrm{w} / \mathrm{w}))$ and $C_{p}$ is the permeate BSA concentration.

169

170 The hydraulic resistance $(R)$ was determined by means of Darcy's law (Eq. 2) at the end of 171 each fouling run. 


$$
J=\frac{\Delta P}{\mu \cdot R}
$$

Eq. 2

174

175 where $J$ is the permeate flux, $\Delta P$ is the transmembrane pressure, $R$ is the total hydraulic

176 resistance and $\mu$ is the feed solution viscosity.

177

178

\subsubsection{Rinsing and cleaning experiments}

179

180 After the fouling experiments, a washing step with deionized water prior to membrane 181 cleaning (first rinsing) was performed to remove the reversible fouling from the 182 membrane. Then, a cleaning step with $\mathrm{NaCl}$ solutions that allows the removal of the 183 irreversible fouling was carried out. After the cleaning procedure, another rinsing step 184 (second rinsing) with deionized water can be performed in order to remove the remaining 185 loose foulant matter from the membrane surface and the cleaning agent molecules.

187 Cleaning experiments were performed at a transmembrane pressure of $1 \mathrm{bar}$, different 188 crossflow velocities $\left(1.2,1.69,2.18,2.68,3.19\right.$ and $\left.4.2 \mathrm{~m} \cdot \mathrm{s}^{-1}\right)$, five $\mathrm{NaCl}$ concentrations $(0$, $1892.5,5,7.5$ and $10 \mathrm{mM})$ and three temperatures $\left(25,37.5\right.$ and $\left.50^{\circ} \mathrm{C}\right)$. The $\mathrm{pH}$ of all the

$190 \mathrm{NaCl}$ solutions ranged from 6.8 to 7 . Each cleaning procedure was performed in duplicate.

191 Before and after the cleaning step the membranes were rinsed at $25{ }^{\circ} \mathrm{C}$ and the same 192 transmembrane pressure and crossflow velocity as the cleaning step. During the rinsing 193 and cleaning steps, low transmembrane pressure (1 bar) favours the relaxation of the 194 compressible fouling layer formed in the fouling step and its removal [6]. 
196 The steps of cleaning and rinsing ended when the permeate flux and the hydraulic

197 resistance of each step remained constant with time. The duration of the rinsing steps was

19845 minutes, while the duration of the cleaning step ranged from 70 to 80 minutes.

200 After the last rinsing step, if the initial permeability conditions of the membranes were not

201 recovered, membranes were cleaned with alkaline solutions. Polymeric membranes (5 and

$20230 \mathrm{kDa}$ ) were cleaned with $\mathrm{NaOH}$ aqueous solutions at $45^{\circ} \mathrm{C}$ and a $\mathrm{pH}$ of 11 . The $15 \mathrm{kDa}$

203 membrane was cleaned with $250 \mathrm{ppm} \mathrm{NaClO}$ aqueous solutions at a $\mathrm{pH}$ of 11 . These

204 cleaning procedures were recommended by the manufacturers to restore the membrane 205 permselectivity properties.

\subsection{Evaluation of membrane cleanliness}

208

209 Daufin et al. [20] and Matzinos and Álvarez [19] developed a method to calculate the

210 efficiency of rinsing and cleaning protocols. In these works, membranes were cleaned with

$211 \mathrm{NaOH}$ solutions and the hydraulic resistance of the membrane after each step (fouling, first

212 rinsing, cleaning and second rinsing) was determined by means of Darcy's law. These 213 authors proposed an equation to evaluate the efficiency of the first rinsing to restore the

214 membrane permeability. To evaluate the cleaning efficiency of the entire cleaning protocol

215 to restore the initial membrane permeability, a similar equation (Eq. 3) was used [19, 20, 216 21]:

$$
H C E=\frac{R_{f}-R_{r 2}}{R_{f}-R_{m}} \cdot 100
$$


where $H C E$ is the hydraulic cleaning efficiency, $R_{f}$ is the fouling resistance, $R_{m}$ is the resistance of the new membrane and $R_{r 2}$ is the hydraulic resistance after the second rinsing.

\subsection{Statistical and optimization analysis}

Results of the cleaning experiments were used to determine the relationship between the values of the cleaning operating conditions (temperature, $T_{c}, \mathrm{NaCl}$ concentration, $C$, and crossflow velocity, v) and the HCE by means of a Response Surface Methodology (RSM) analysis. This analysis was performed with the Statgraphics ${ }^{\circledR}$ software using a factorial design. After that, a Multiple Linear Regression analysis was carried out to obtain a model equation for $\mathrm{HCE}$ as a function of the operating conditions studied. In a first step, $T_{c}, C, v$ and their interactions were considered. If a regression model coefficient had a p-value higher than 0.05 , it was neglected because it was not statistically significant. Thus, a new regression analysis was performed until all the coefficients were statistically significant.

To determine the values of temperature, $\mathrm{NaCl}$ concentration and crossflow velocity that maximize the value of HCE for each membrane tested, an optimization method was performed with the model equations obtained in the RSM analysis. The optimization algorithm was based on the "patternsearch" function of Matlab® software, which finds the minimum of an objective function by means of a pattern search. Therefore, in this work the

240 objective functions are the opposite functions of the model equations of HCE for each 241 membrane. Additional parameters were included in the "patternsearch" function as the maximum value of temperature $\left(50^{\circ} \mathrm{C}\right)$ and the maximum value of crossflow velocity

$243\left(3.19 \mathrm{~m} \cdot \mathrm{s}^{-1}\right.$ for the 5 and $30 \mathrm{kDa}$ membranes and $4.2 \mathrm{~m} \cdot \mathrm{s}^{-1}$ for the $15 \mathrm{kDa}$ membrane), as

244 these were the higher values tested of these operating conditions. 


\subsection{AFM measurements}

247

248 A Multimode Atomic Force Microscope (supplied by Veeco, Santa Barbara, CA, USA)

249 with a NanoScope V controller was used to measure membranes roughness. Samples of 5

$250 \mu \mathrm{m} \times 5 \mu \mathrm{m}$ samples were used. Roughness was obtained by means of the tapping mode of

251 imaging and the results were presented in terms of the Root Mean Square roughness $\left(R_{q}\right)$.

252 This parameter considers the standard deviation of the surface height values in a specific 253 area (Eq. 4) [22]:

$$
R_{q}=\sqrt{\frac{\sum\left(Z_{i}-Z_{a v g}\right)^{2}}{N_{p}}}
$$

Eq. 4

257 In this equation, $N_{p}$ is the number of points in the selected area, $Z_{i}$ is the height value 258 currently measured and $Z_{\text {avg }}$ is the average of the height values.

259

260

\section{Results and discussion}

261

262 The values of $R_{m}$ for the membranes used in the experiments were: $9.453 \cdot 10^{12}, 5.001 \cdot 10^{12}$

263 and $3.794 \cdot 10^{12} \mathrm{~m}^{-1}$, for the membranes of 5,15 and $30 \mathrm{kDa}$, respectively. These values

264 were taken as a reference to calculate HCE.

265

266

\subsection{Fouling experiments}

267 
268 Evolution of permeate flux with time during the fouling step for the 5, 15 and $30 \mathrm{kDa}$

269 membranes is shown in Fig. 1. Among all the membranes tested, the PESH $30 \mathrm{kDa}$ 270 membrane showed the lowest flux decline (19.96\%) during the fouling step in comparison 271 with the PES $5 \mathrm{kDa}$ membrane (34.62\%) and the ceramic $15 \mathrm{kDa}$ membrane (39.82\%).

272 The reason for that is the hydrophilic nature of the $30 \mathrm{kDa}$ membrane. According to 273 Rahimpour and Madaeni [23], the higher the hydrophilicity of the membrane surface is, the 274 better the antifouling properties (high rejection coefficient, low permeate flux decline and 275 low total filtration resistance) are. These authors tested the behavior of several PES 276 membranes during the crossflow filtration of non-skim milk. Their results demonstrated 277 that the hydrophilic PES membranes had a lower permeate flux decline (about $16 \%$ ) than 278 the unmodified hydrophobic PES membrane (about $40 \%$ ). In addition, protein rejection 279 was higher for the hydrophilic membranes than for the hydrophobic one. On the other 280 hand, membrane fouling is also related to the surface roughness. When membrane 281 roughness increases, fouling becomes more severe, because rougher surfaces favour the 282 entrapment of foulant molecules [24]. This phenomenon can be observed for the 283 membranes tested comparing permeate flux decline with the values of roughness $\left(R_{q}\right)$ for 284 each membrane tested. The highest flux decline was achieved for the $15 \mathrm{kDa}$ membrane $285\left(R_{q}=17.900 \mathrm{~nm}\right)$, followed by the $5 \mathrm{kDa}$ membrane $\left(R_{q}=0.487 \mathrm{~nm}\right.$ and hydrophobic $)$ and 286 the $30 \mathrm{kDa}$ membrane $\left(R_{q}=1.657 \mathrm{~nm}\right.$ and hydrophilic).

288 The variation of the rejection coefficient with time for the 5, 15 and $30 \mathrm{kDa}$ membranes 289 during the fouling step can be observed in Fig. 2. After 120 min of UF, BSA rejection was 290 very similar for all the membranes tested $(99.55 \%, 99.64 \%$ and $99.61 \%$ for the 5,15 and $29130 \mathrm{kDa}$ membrane, respectively). These high rejection coefficients may be due to the great 292 difference between the size of BSA molecules and the membrane pore size. When the 
293 foulant molecule size is much higher than the membrane pore size, these molecules can be

294 retained on the membrane surface $[25,26]$.

295

296 Fig. 3 shows the evolution of the hydraulic resistance during the fouling, first rinsing, 297 cleaning and second rinsing steps. The experimental conditions of transmembrane 298 pressure, temperature and crossflow velocity were the same for all the membranes tested in 299 the rinsing and cleaning steps: $1 \mathrm{bar}, 2.18 \mathrm{~m} \cdot \mathrm{s}^{-1}$ and $25^{\circ} \mathrm{C}$ during the rinsing steps and 1 300 bar, $2.18 \mathrm{~m} \cdot \mathrm{s}^{-1}$ and $50{ }^{\circ} \mathrm{C}$ in the cleaning step. However, $\mathrm{NaCl}$ concentration was higher for 301 the polymeric membranes $(7.5 \mathrm{mM})$ than in the case of the ceramic one $(5 \mathrm{mM})$, because 302 these were the values of $\mathrm{NaCl}$ concentration to obtain the highest $\mathrm{HCE}$ for each membrane 303 at the experimental conditions above mentioned. According to Fig. 3, the HCE obtained for 304 the $15 \mathrm{kDa}$ membrane was the lowest (56.27\%), while the HCE for the 5 and $30 \mathrm{kDa}$ membranes were higher than $90 \%(90.98 \%$ and $98.43 \%$, respectively). The reason for

306 that is the higher roughness of the $15 \mathrm{kDa}$ membrane compared with the 5 and $30 \mathrm{kDa}$ 307 membranes ( $R_{q}$ values of 0.487 and $1.657 \mathrm{~nm}$, respectively). Therefore, higher values of 308 crossflow velocity were tested for the $15 \mathrm{kDa}$ membrane in order to achieve greater values 309 of HCE.

\subsection{Cleaning experiments}

\section{3.2.1. Influence of $\mathrm{NaCl}$ concentration}

315 The effect of $\mathrm{NaCl}$ concentration on the values of $\mathrm{HCE}$ for each membrane was

316 investigated. Several $\mathrm{NaCl}$ concentrations $(0,2.5,5,7.5,10$ and $12.5 \mathrm{mM})$ at two different 317 temperatures $\left(25\right.$ and $\left.50{ }^{\circ} \mathrm{C}\right)$ were considered. Crossflow velocity was set at $2.18 \mathrm{~m} \cdot \mathrm{s}^{-1}$ for 
318 the polymeric membranes (5 and $30 \mathrm{kDa})$ and at $4.2 \mathrm{~m} \cdot \mathrm{s}^{-1}$ for the $15 \mathrm{kDa}$ membrane. Fig. 4

319 shows the results of the influence of $\mathrm{NaCl}$ concentration on the HCE. In the case of the 320 polymeric membranes, $\mathrm{HCE}$ increased as $\mathrm{NaCl}$ concentration increased up to $7.5 \mathrm{mM}$ for

321 the two temperatures tested. However, above this salt concentration, HCE decreased (Figs.

$3224 \mathrm{a}$ and $4 \mathrm{c}$ ). The same effect can be observed in Fig. $4 \mathrm{~b}$ for the ceramic membrane: HCE

323 increased as $\mathrm{NaCl}$ concentration increased up to $5 \mathrm{mM}$, but a higher increase in salt

324 concentration caused a decrease in HCE for both temperatures studied. It can also be 325 observed that, at the same experimental conditions $\left(50{ }^{\circ} \mathrm{C}\right.$ and $7.5 \mathrm{mM}$ of $\left.\mathrm{NaCl}\right)$, the

326 highest value of HCE was obtained for the $30 \mathrm{kDa}$ membrane $(98.42 \%)$. The reason for 327 this is the hydrophilic nature of the $30 \mathrm{kDa}$ membrane as well as the small roughness that 328 this membrane presents. Thus, this membrane showed less severe fouling than that of the 5

329 and $15 \mathrm{kDa}$ membranes as it was already commented and it can be cleaned more easily $330 \quad[23]$.

332 Other authors $[10,14,27]$ observed as well that there is an optimal value of the cleaning 333 agents to clean different membranes. They reported that the cleaning efficiency increased 334 as their concentration increased up to this optimal concentration. However, the cleaning 335 efficiency did not increase or it could even decrease if the cleaning agent concentration 336 increased above the optimal value. Lee and Elimelech [14] used $\mathrm{NaCl}$ solutions at different 337 concentrations $(0,10,25,50,100$ and $300 \mathrm{mM})$ to clean reverse osmosis membranes 338 fouled with alginate and calcium solutions. They achieved HCE values of about $90 \%$ at a

$339 \mathrm{NaCl}$ concentration of $50 \mathrm{mM}$. However, when $\mathrm{NaCl}$ concentration increased, the values of

340 HCE remained constant. This may be due to the fact that the physical conditions for 341 effective mass transfer were below the optimal ones [14]. Cabero Cabero [27] used 342 conventional cleaning agents (alkaline and detergent aqueous solutions) to clean a ceramic 
343 UF membrane fouled with whey protein concentrate solutions. This author reported that

344 fouling and cleaning mechanisms may become competitive and that the cleaning agent

345 molecules can be accumulated on the membrane surface or inside its pores. In addition,

346 Tsumoto et al. [10] studied the effect of several salt concentrations on the surface tension.

347 At low salt concentrations, the surface tension decreases as salt concentration increases,

348 but the surface tension increases linearly with concentration at high salt concentrations.

349 They also demonstrated that the salting-in effects of saline solutions are enhanced with a 350 decrease in the surface tension. Thus, the salting-in effects of $\mathrm{NaCl}$ solutions are better 351 observed at low salt concentrations.

\subsubsection{Influence of cleaning solution temperature}

355 Cleaning experiments were performed at three temperatures $\left(25,37.5\right.$ and $\left.50{ }^{\circ} \mathrm{C}\right)$ and two different $\mathrm{NaCl}$ concentrations and crossflow velocities $\left(7.5 \mathrm{mM}\right.$ and $2.18 \mathrm{~m} \cdot \mathrm{s}^{-1}$ for the

357 polymeric membranes and $5 \mathrm{mM}$ and $4.2 \mathrm{~m} \cdot \mathrm{s}^{-1}$ for the ceramic membrane) to investigate 358 the effect of the cleaning solution temperature on HCE for each membrane tested. The

359 results obtained are shown in Fig. 5. As it can be observed, HCE increases as cleaning 360 solution temperature increases for all the membranes tested. The highest HCE values $361(90.98 \%, 99.05 \%$ and $98.43 \%)$ were achieved at the highest temperature tested $\left(50{ }^{\circ} \mathrm{C}\right)$

362 for the membranes of 5, 15 and $30 \mathrm{kDa}$ respectively.

364 Some authors related the surface tension of a saline solution to the temperature [28, 29]. As

365 temperature increases, the hydrophilic ions are adsorbed from the air/water surface and

366 thus, the surface tension of the saline solution decreases [30]. As it was explained in 367 section 3.2.1., the lower the surface tension is, the more enhanced the salting-in effects are 
368 [10]. On the other hand, temperatures up to $50{ }^{\circ} \mathrm{C}$ increase protein solubility and can

369 weaken the structural stability of the fouling layer, swelling it and favouring its removal

370 from the membrane surface [31]. The rate of foulant molecules transferred from the

371 membrane surface to the feed solution also increases when the cleaning solution

372 temperature increases, due to the increase in the diffusivity coefficient as temperature rises.

373 Moreover, the rate of the interaction between the salt and the deposited proteins may be

374 increased by an increase in temperature [14].

375

376 For all these reasons, the highest temperature tested $\left(50^{\circ} \mathrm{C}\right)$ is the most convenient 377 temperature to perform the cleaning process when the membranes are fouled with BSA and $378 \mathrm{CaCl}_{2}$ solutions.

379

380

\subsubsection{Influence of crossflow velocity}

381

382 Fig. 6 shows the variation of HCE with crossflow velocity for all the membranes tested.

383 The values of $\mathrm{NaCl}$ concentration and temperature that were selected to study the influence

384 of the crossflow velocity on HCE were the ones at which the highest values of HCE were 385 obtained. These conditions were a $\mathrm{NaCl}$ concentration of $7.5 \mathrm{mM}$ and $50{ }^{\circ} \mathrm{C}$ for the 386 polymeric membranes and a $\mathrm{NaCl}$ concentration of $5 \mathrm{mM}$ and $50{ }^{\circ} \mathrm{C}$ for the ceramic 387 membrane. In the case of the 5 and $30 \mathrm{kDa}$ membranes (Fig. 6a), lower values of crossflow 388 velocity were tested $\left(1.2\right.$ and $\left.1.69 \mathrm{~m} \cdot \mathrm{s}^{-1}\right)$, due to the lower roughness of these membranes 389 compared with the ceramic one.

391 The Fig. 6 shows that when crossflow velocity increases, HCE increases. For all the

392 membranes tested, values of HCE near $100 \%$ were achieved at the highest crossflow 
393 velocity tested $\left(3.19 \mathrm{~m} \cdot \mathrm{s}^{-1}\right.$ for the 5 and $30 \mathrm{kDa}$ membranes and $4.2 \mathrm{~m} \cdot \mathrm{s}^{-1}$ for the $15 \mathrm{kDa}$

394 membrane). As the crossflow velocity increases, the shear force increases as well

395 favouring the removal of foulant molecules from the membrane surface $[32,33,34]$.

396

397 3.3. Statistical and optimization analysis

398

399 The influence of the operating conditions (temperature, $\mathrm{NaCl}$ concentration and crossflow 400 velocity) on the values of HCE was evaluated by means of statistical (RSM and Multiple

401 Linear Regression) and optimization (pattern search algorithm) analysis.

402

403 The effect of temperature and $\mathrm{NaCl}$ concentration on $\mathrm{HCE}$ for the 5, 15 and $30 \mathrm{kDa}$

404 membranes is shown in Fig. 7. Light grey and white colours in the lower left corner of the 405 surface contours represented the most unfavourable conditions to perform the cleaning procedure. These conditions corresponded to the lowest temperature $\left(25^{\circ} \mathrm{C}\right)$ and $\mathrm{NaCl}$ concentration $(0 \mathrm{mM})$ tested. On the other hand, the highest values of HCE (higher than 90

\%) were achieved at temperatures higher than $46-50{ }^{\circ} \mathrm{C}$ and $\mathrm{NaCl}$ concentrations ranging

409 from 7.5 to $10 \mathrm{mM}$ for the 5 and $30 \mathrm{kDa}$ membranes and from 4.5 to $5 \mathrm{mM}$ in the case of

410 the $15 \mathrm{kDa}$ membrane. These experimental conditions are coloured in black in Fig. 7.

411

412 After the RSM analysis, a Multiple Linear Regression was performed to relate HCE with 413 temperature, $\mathrm{NaCl}$ concentration and crossflow velocity. Eqs. 5, 6 and 7 show these 414 mathematical relationships for the 5, 15 and $30 \mathrm{kDa}$ membranes, respectively. The 415 regression coefficients for each equation were $0.976,0.970$ and 0.962 , respectively. Table 4162 shows the results of the ANOVA. 
424 In these equations, $H C E_{5}, H C E_{15}$ and $H C E_{30}$ are the hydraulic cleaning efficiencies for the membranes of 5,15 and $30 \mathrm{kDa}$, respectively, $T_{c}$ is the temperature of the cleaning solution $\left({ }^{\circ} \mathrm{C}\right), C$ is the $\mathrm{NaCl}$ concentration $(\mathrm{mM}), v$ is the crossflow velocity $\left(\mathrm{m} \cdot \mathrm{s}^{-1}\right)$ and a, b, c, d, e,

$\mathrm{f}, \mathrm{g}$ and $\mathrm{h}$ are the estimated coefficients for each statistically significant parameter. Their estimated values are shown in Table 2.

The values of the coefficients of the significant parameters are in agreement with the experimental observations. Within the range of values of the operating parameters considered in this work, the equations for the polymeric membranes predicted that HCE 433 increases with $v$ and decreases with $v^{2}$. The values of the coefficients indicate that the 434 increase in HCE with this variable was much more significant at low values of $v$, while at the largest values of $v$ the increase in HCE was much lower. However, in the case of the ceramic membrane HCE was highly affected by $v$ and linearly increased with this variable

437 for all the operating conditions tested, probably due to the greater roughness of this 438 membrane. The model equations predicted as well that HCE was highly affected by $T_{c}$ and 439 it significantly increased with this variable for all the membranes. Regarding the effect of $440 \mathrm{NaCl}$ concentration on $\mathrm{HCE}$, the model equations predicted that HCE increased with $C$ and 441 decreased with $C^{2}$. This indicates that at low values of $\mathrm{NaCl}$ concentration $\mathrm{HCE}$ increases 442 with this variable up to an optimum concentration and a further increase in $\mathrm{NaCl}$ 
443 concentration caused a decrease in HCE. For some of the membranes there was an

444 interaction between concentration and temperature, which indicates that the effect of 445 concentration on $\mathrm{HCE}$ is greater at higher $\mathrm{NaCl}$ concentrations and vice versa.

446

447 Results of the optimization analysis based on the "patternsearch" function of Matlab® are

448 shown in Table 3. According to them, the optimal cleaning solution temperature was $50{ }^{\circ} \mathrm{C}$

449 for all the membranes tested. Optimal values of crossflow velocity and $\mathrm{NaCl}$ concentration

450 were: $3.15 \mathrm{~m} \cdot \mathrm{s}^{-1}$ and $10 \mathrm{mM}$ for the $5 \mathrm{kDa}$ membrane, $4.2 \mathrm{~m} \cdot \mathrm{s}^{-1}$ and $7.17 \mathrm{mM}$ for the 15

$451 \mathrm{kDa}$ membrane and $2.82 \mathrm{~m} \cdot \mathrm{s}^{-1}$ and $9.76 \mathrm{mM}$ for the $30 \mathrm{kDa}$ membrane.

452

453

4. Conclusions

454

455

- Three different ultrafiltration membranes of 5, 15 and $30 \mathrm{kDa}$ that had been previously

456 fouled with whey model solutions consisting of BSA $(1 \% \mathrm{w} / \mathrm{w})$ and $\mathrm{CaCl}_{2}(0.06 \%$

$457 \quad \mathrm{w} / \mathrm{w}$ in calcium) were effectively cleaned with $\mathrm{NaCl}$ solutions. $\mathrm{NaCl}$ was effective as a

458 cleaning agent at the experimental conditions tested due to the salting-in effect of this

$459 \quad$ salt.

460

461 - An increase in temperature and crossflow velocity resulted in an increase in HCE.

462

463 - There was an optimal value of $\mathrm{NaCl}$ concentration to clean the membranes. If $\mathrm{NaCl}$

464 concentration increased up to this optimal value, HCE increased; but a further increase

465 in $\mathrm{NaCl}$ concentration caused a decrease in the values of HCE.

466 
- The optimal operating conditions that resulted in the maximum values of HCE (about $468 \quad 100 \%$ ) were: a temperature of $50{ }^{\circ} \mathrm{C}$ for all the membranes, a crossflow velocity of $4693.15 \mathrm{~m} \cdot \mathrm{s}^{-1}$ and a $\mathrm{NaCl}$ concentration of $10 \mathrm{mM}$ for the $5 \mathrm{kDa}$ membrane, a crossflow 470 velocity of $4.2 \mathrm{~m} \cdot \mathrm{s}^{-1}$ and $\mathrm{NaCl}$ concentration of $7.17 \mathrm{mM}$ for the $15 \mathrm{kDa}$ membrane 471 and a crossflow velocity of $2.82 \mathrm{~m} \cdot \mathrm{s}^{-1}$ and a $\mathrm{NaCl}$ concentration of $9.76 \mathrm{mM}$ for the 30 $472 \quad$ kDa membrane.

473

- Mathematical relationships between HCE and the operating conditions were 475 determined for all the membranes considered using a multiple linear regression $476 \quad$ analysis.

477

478 Acknowledgements

479

480 The authors of this work wish to gratefully acknowledge the financial support from the 481 Spanish Ministry of Science and Innovation through the project CTM2010-20186 and the 482 Generalitat Valenciana through the program "Ayudas para la realización de proyectos I+D 483 para grupos de investigación emergentes GV/2013”.

485 Nomenclature

486

487 List of symbols

488

489 a $\quad$ Model equation coefficient (\%)

$490 \quad \mathrm{~b} \quad$ Model equation coefficient $\left(\mathrm{m}^{-1} \cdot \mathrm{s}\right)$

491 c $\quad$ Model equation coefficient $\left({ }^{\circ} \mathrm{C}^{-1} \cdot \mathrm{mM}^{-1}\right)$ 


\begin{tabular}{|c|c|c|}
\hline 492 & $\mathrm{C}$ & $\mathrm{NaCl}$ concentration $(\mathrm{mM})$ \\
\hline 493 & $\mathrm{C}_{\mathrm{b}}$ & 3SA concentration in the feed solution $\left(g \cdot \mathrm{L}^{-1}\right)$ \\
\hline 494 & $\mathrm{C}_{\mathrm{p}}$ & $3 S A$ concentration in the permeate $\left(\mathrm{g} \cdot \mathrm{L}^{-1}\right)$ \\
\hline 495 & $\mathrm{M}$ & Model equation coefficient $\left({ }^{\circ} \mathrm{C}^{-2}\right)$ \\
\hline 496 & M & Model equation coefficient $\left(\mathrm{mM}^{-2}\right)$ \\
\hline 497 & M & Model equation coefficient $\left(\mathrm{m}^{-2} \cdot \mathrm{s}^{2}\right)$ \\
\hline 498 & M & Model equation coefficient $\left({ }^{\circ} \mathrm{C}^{-1}\right)$ \\
\hline 499 & $\mathrm{~h}$ & Model equation coefficient $\left(\mathrm{mM}^{-1}\right)$ \\
\hline 500 & $\mathrm{Pc}$ & ermeate flux $\left(\mathrm{m}^{3} \cdot \mathrm{m}^{-2} \cdot \mathrm{s}^{-1}\right)$ \\
\hline 501 & $N_{p}$ & Number of points within the given area (dimensionless) \\
\hline 502 & $\Delta \mathrm{P}$ & Transmembrane pressure (bar) \\
\hline 503 & $\mathrm{R}$ & Total hydraulic resistance $\left(\mathrm{m}^{-1}\right)$ \\
\hline 504 & $\mathrm{R}_{\mathrm{m}}$ & Resistance of the new membrane $\left(\mathrm{m}^{-1}\right)$ \\
\hline 505 & $\mathrm{R}_{\mathrm{f}}$ & Resistance after the fouling step $\left(\mathrm{m}^{-1}\right)$ \\
\hline 506 & $\mathrm{R}_{\mathrm{r} 1}$ & Resistance after the first rinsing step $\left(\mathrm{m}^{-1}\right)$ \\
\hline 507 & $\mathrm{R}_{\mathrm{c}}$ & Resistance after the cleaning step $\left(\mathrm{m}^{-1}\right)$ \\
\hline 508 & $\mathrm{R}_{\mathrm{r} 2}$ & Resistance after the second rinsing step $\left(\mathrm{m}^{-1}\right)$ \\
\hline 509 & $\mathrm{Fi}$ & Giltration time (s) \\
\hline 510 & $\mathrm{~T}_{\mathrm{c}}$ & Temperature of the cleaning solution $\left({ }^{\circ} \mathrm{C}\right)$ \\
\hline 511 & $v$ & Crossflow velocity $\left(\mathrm{m} \cdot \mathrm{s}^{-1}\right)$ \\
\hline 512 & $\mathrm{Z}_{\mathrm{i}}$ & Value of height currently measured (nm) \\
\hline 513 & $\mathrm{Z}_{\text {avg }}$ & Average of the height values of the sample (nm) \\
\hline 514 & & \\
\hline 515 & \multicolumn{2}{|l|}{ Greek letters } \\
\hline
\end{tabular}


$517 \mu \quad$ Feed solution viscosity $\left(\mathrm{kg} \cdot \mathrm{m}^{-1} \cdot \mathrm{s}^{-1}\right)$

518

519 Abbreviations

520

521 AFM Atomic force microscopy

522 BSA Bovine serum albumin

523 HCE Hydraulic cleaning efficiency

524 HRE Hydraulic rinsing efficiency

525 MWCO Molecular weight cut off

526 PES Polyethersulfone

527 pI Isoelectric point

528 RSM Response surface methodology

529 UF Ultrafiltration

530

\section{$531 \quad$ References}

532

533 [1] O.O. Ogunbiyi, N.J. Miles, N. Hilal, The effects of performance and cleaning cycles of 534 new tubular ceramic microfiltration membrane fouled with a model yeast suspension, 535 Desalination 220 (2008) 273-289.

536 [2] M. Kazemimoghadam, T. Mohammadi, Chemical cleaning of ultrafiltration membranes 537 in the milk industry, Desalination 204 (2007) 213-218.

538 [3] M.C. Almécija, A. Martínez-Férez, A. Guadix, M.P. Páez, E.M. Guadix, Influence of 539 the cleaning temperature on the permeability of ceramic membranes, Desalination 245 $540 \quad$ (2009) 708-713. 
541 [4] W.S. Ang, M. Elimelech, Protein (BSA) fouling of reverse osmosis membranes:

542 Implications for wastewater reclamation, J. Membr. Sci. 296 (2007) 83-92.

543 [5] H. Mo, K.G. Tay, H.Y. Ng, Fouling of reverse osmosis membrane by protein (BSA):

544 Effects of $\mathrm{pH}$, calcium, magnesium, ionic strength and temperature, J. Membr. Sci. 315

545 (2008) 28-35.

546 [6] P. Blanpain-Avet, J.F. Migdal, T. Bénézech, Chemical cleaning of a tubular ceramic

547 microfiltration membrane fouled with a whey protein concentrate suspension-

548 Characterization of hydraulic and chemical cleanliness, J. Membr. Sci. 337 (2009) 153549174.

550 [7] M.C. Almécija, J.E. Zapata, A. Martínez-Férez, A. Guadix, A. Hernández, J.I. Calvo, 551 E.M. Guadix, Analysis of cleaning protocols in ceramic membranes by liquid-liquid 552 displacement porosimetry, Desalination 245 (2009) 541-545.

553 [8] C.C. Taragaza, M.E. Campderrós, A. Pérez Padilla, Physical cleaning by means of 554 electric field in the ultrafiltration of a biological solution, J. Membr. Sci. 278 (2006) 219555224

556 [9] S. Muthukumaran, K. Yang, A. Seuren, S. Kentish, M. Ashokkumar, G.W. Stevens, R.

557 Grieser, The use of ultrasonic cleaning for ultrafiltration membranes in the dairy industry, 558 Sep. Purif. Technol. 39 (2004) 99-107.

559 [10] K. Tsumoto, D. Ejima, A.M. Senczuk, Y. Kita, T. Arakawa, Effects of salts on 560 protein-surface interactions: Applications for column chromatography, J. Pharmaceutical 561 Sci. $96(2007)$ 1677-1690.

562 [11] J. Zhang, Chapter 18: Protein-protein interactions in salt solutions, in: W. Cai, H. 563 Hong (Eds.) Protein-protein interactions - Computational and experimental tools, Intech, 564 2012, pp. 359- 376. 
565 [12] F. Hofmeister, Zur lehre von der wirkung der salze, Arch. Exp. Pathol. Pharmakol. 24

$566 \quad(1888) 247$.

567 [13] N.V. Nucci, J.M. Vanderkooi, Effects of salts of the Hofmeister series on the 568 hydrogen bond network of water, J. Mol. Liq. 143 (2008) 160-170.

569 [14] S. Lee, M. Elimelech, Salt cleaning of organic-fouled reverse osmosis membranes, $570 \quad$ Water Res. 41 (2007) 1134-1142.

571 [15] M-J. Corbatón-Báguena, S. Álvarez-Blanco, M-C. Vincent-Vela, Cleaning of 572 ultrafiltration membranes fouled with BSA by means of saline solutions, Sep. Purif. 573 Technol. 125 (2014) 1-10.

574 [16] P. Suttiprasit, V. Krisdhasima, J. McGuire, The surface activity of $\alpha$-lactalbumin, $\beta$ 575 lactoglobulin and bovine serum albumin, J. Colloid Interface Sci., 154 (1992) 316-326.

576 [17] Y-N. Wang, C.Y. Tang, Protein fouling of nanofiltration, reverse osmosis, and 577 ultrafiltration membranes-The role of hydrodynamic conditions, solution chemistry and 578 membrane properties, J. Membr. Sci. 376 (2011) 275-282.

579 [18] A. Afonso, J.M. Miranda, J.B.L.M. Campos, Numerical study of BSA ultrafiltration in 580 the limiting flux regime - Effect of variable physical properties, Desalination 249 (2009) $581 \quad 1139-1150$

582 [19] P. Matzinos, R. Álvarez, Effect of ionic strength on rinsing and alkaline cleaning of 583 ultrafiltration inorganic membranes fouled with whey proteins, J. Membr. Sci. 208 (2002) $584 \quad 23-30$.

585 [20] G. Daufin, J.-P. Escudier, H. Carrère, S. Bérot, L. Fillaudeau, M. Decloux, Recent and 586 emerging applications of membrane processes in the food and dairy industry, Food 587 Bioprod. Process. 79 (2001) 89-102. 
588 [21] S. Muthukumaran, S.E. Kentish, G.W. Stevens, M. Ashokkumar, R. Mawson, The 589 application of ultrasound to dairy ultrafiltration: The influence of operating conditions, J. $590 \quad$ Food Eng. 81 (2007) 364-373.

591 [22] T.-S. Chung, J.-J. Qin, A. Huan, K.-C. Toh, Visualization of the effect of die shear 592 rate on the outer surface morphology of ultrafiltration membranes by AFM, J. Membr. Sci. $593196(2002) 251-266$.

594 [23] A. Rahimpour, S.S. Madaeni, Improvement of performance and surface properties of 595 nano-porous polyethersulfone (PES) membrane using hydrophilic monomers as additives 596 in the casting solution, J. Membr. Sci. 360 (2010) 371-379.

597 [24] P.J. Evans, M.R. Bird, A. Pihlajamäki, M. Nyström, The influence of hydrophobicity, 598 roughness and charge upon ultrafiltration membranes for black tea liquor clarification, J. 599 Membr. Sci. 313 (2008) 250-262.

600 [25] A.I. Schäfer, A.G. Fane, T.D. Waite, Fouling effects on rejection in the membrane 601 filtration of natural waters, Desalination 131 (2000) 215-224.

602 [26] H.V. Adikane, D.M. Thakar, S.N. Nene, Optimisation of colour and sugar rejection of 603 black liquior using membranes, Sep. Purif. Technol. 36 (2004) 229-234.

604 [27] M.L. Cabero Cabero, Limpieza química de membranas inorgánicas: Aplicación al 605 tratamiento de lactosuero, PhD Thesis, University of Oviedo, 1997.

606 [28] K. Ali, A-u-H.A. Shah, S. Bilal, Thermodynamic parameters of surface formation of 607 some aqueous salt solutions, Colloids and Surfaces A: Physicochem. Eng. Aspects, 330 608 (2008) 28-34.

609 [29] A-u-H.A. Shah, K. Ali, S. Bilal, Surface tension, surface excess concentration, 610 enthalpy and entropy of surface formation of aqueous salt solutions. Colloids and Surfaces 611 A: Physicochem. Eng. Aspects, 417 (2013) 183-190. 
612 [30] N. Matubayasi, R. Yoshikawa, Thermodynamic quantities of surface formation of

613 aqueous electrolyte solutions VII. Aqueous solution of alkali metal nitrates $\mathrm{LiNO}_{3}, \mathrm{NaNO}_{3}$

614 and $\mathrm{KNO}_{3}$, J. Colloid Interface Sci., 315 (2007) 597-600.

615 [31] D.H.G. Pelegrine, C.A. Gasparetto, Whey proteins solubility as function of 616 temperature and pH, Lebensm.-Wiss. u.-Technol, 38 (2005) 77-80.

617 [32] Ü. Daniş, B. Keskinler, Chromate removal from wastewater using micellar enhanced

618 crossflow filtration: Effect of transmembrane pressure and crossflow velocity, 619 Desalination, 249 (2009) 1356-1364.

620 [33] P.J. Smith, H.K. Shon, S. Vigneswaran, H.H. Ngo, H. Nguyen, Productivity 621 enhancement in a cross-flow ultrafiltration membrane system through automated de622 clogging operations, J. Membr. Sci., 280 (2006) 82-88.

623 [34] H. Choi, K. Zhang, D.D. Dionysiou, D.B. Oerther, G.A. Sorial, Influence of cross624 flow velocity on membrane performance during filtration of biological suspension, J. 625 Membr. Sci. 248 (2005) 189-199.

626 


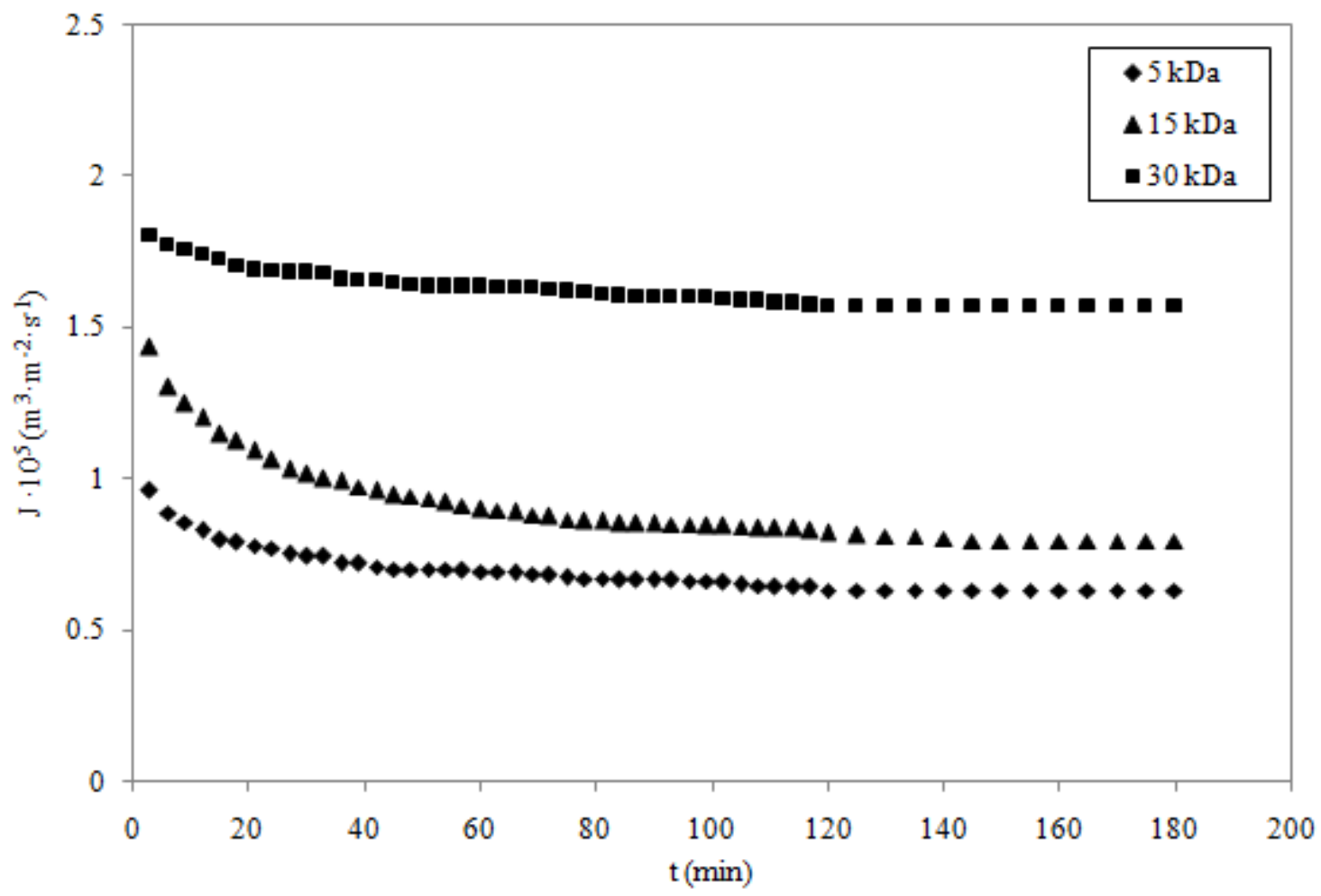

Fig. 1. Variation of permeate flux with time during fouling experiments at $2 \mathrm{bar}, 2 \mathrm{~m} \cdot \mathrm{s}^{-1}$ and $25^{\circ} \mathrm{C}$.

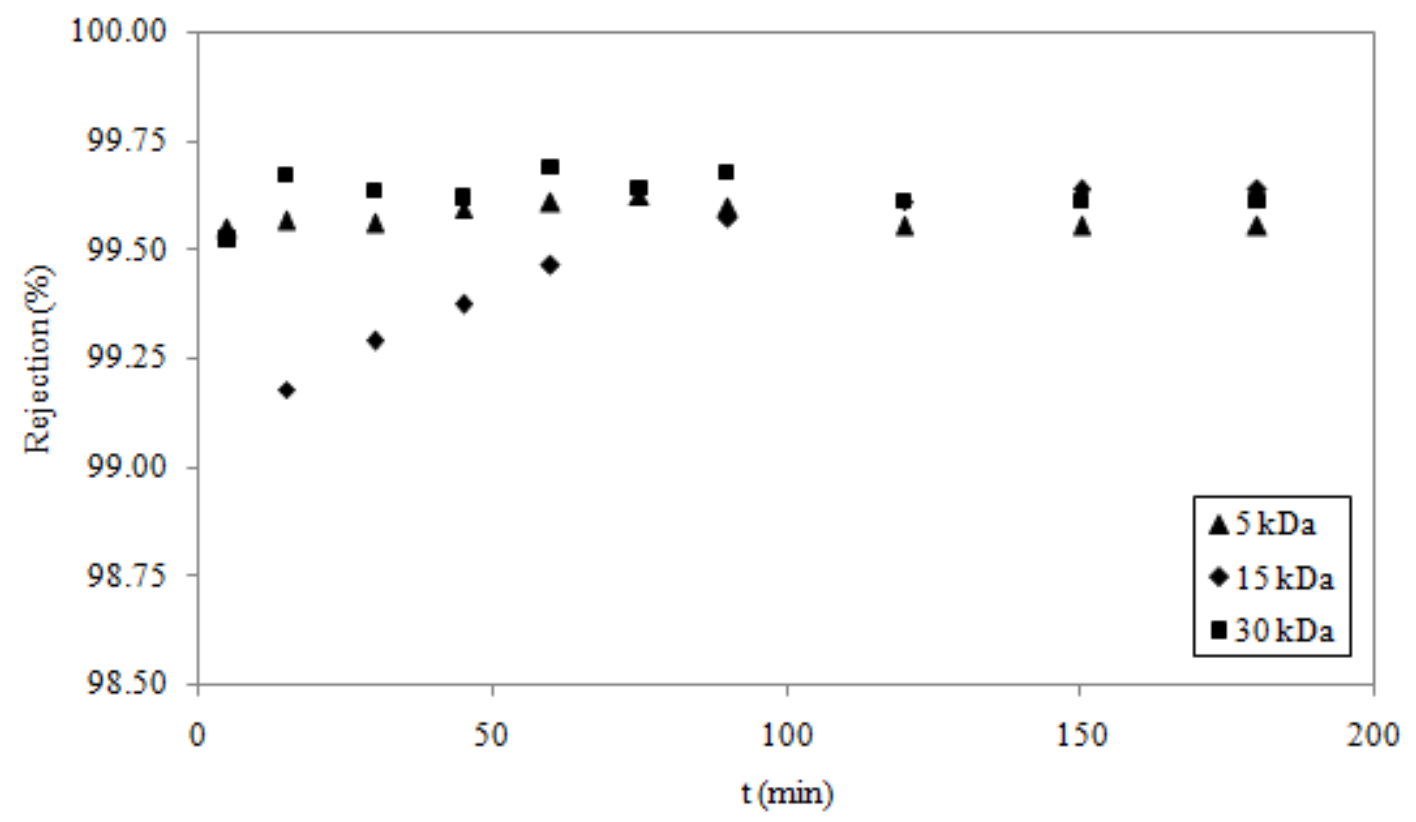

Fig. 2. Variation of BSA rejection with time during the fouling step for each membrane. 


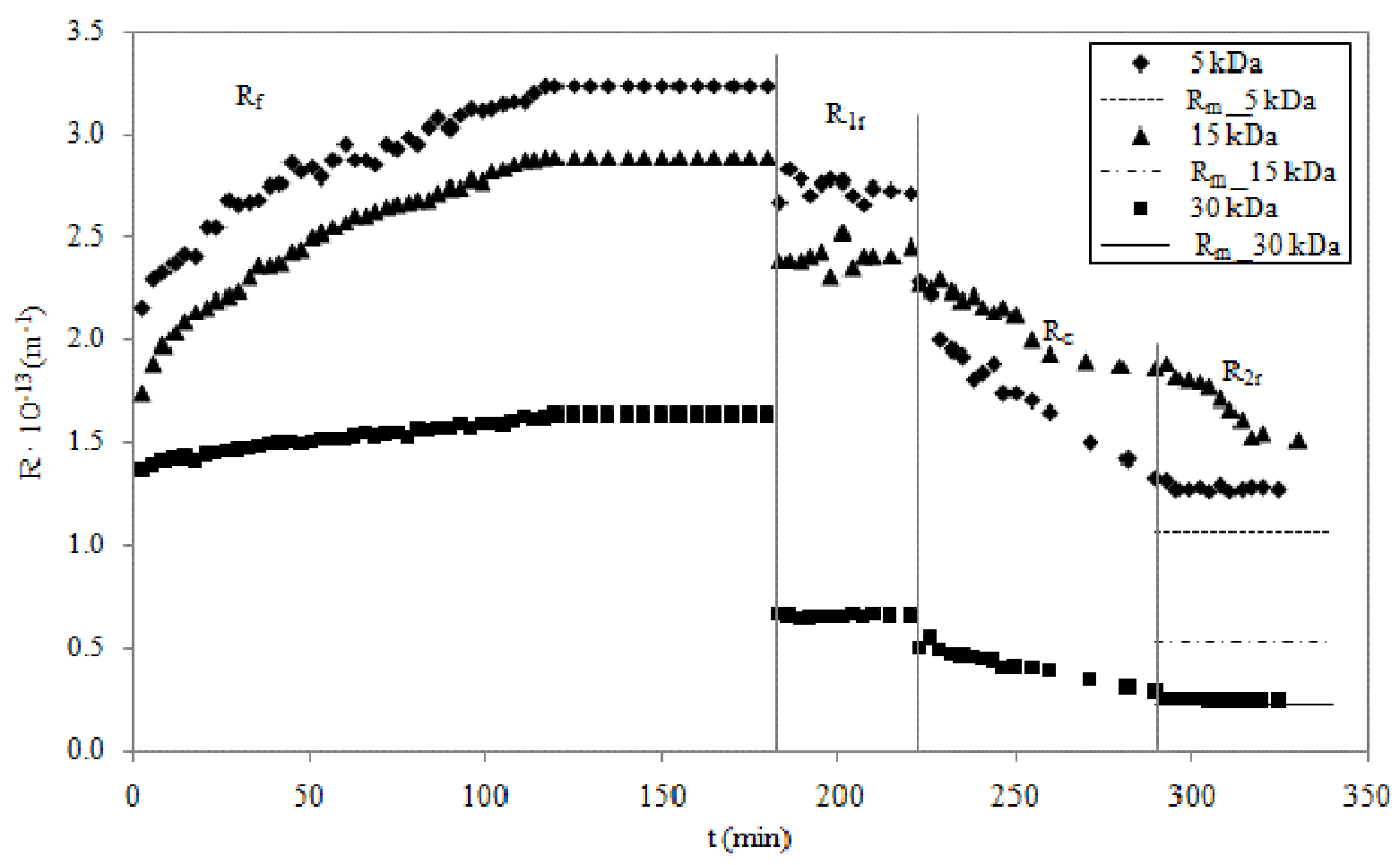

Fig. 3. Variation of total hydraulic resistance with time for each membrane when the experimental conditions were: $25^{\circ} \mathrm{C}, 2$ bar and $2 \mathrm{~m} \cdot \mathrm{s}^{-1}$ in the fouling step; $25^{\circ} \mathrm{C}, 1$ bar and $2.18 \mathrm{~m} \cdot \mathrm{s}^{-1}$ in the rinsing steps; $50^{\circ} \mathrm{C}, 1 \mathrm{bar}$ and $2.18 \mathrm{~m} \cdot \mathrm{s}^{-1}$ in the cleaning step. $\mathrm{NaCl}$ concentration in the cleaning solution was $7.5 \mathrm{mM}$ for the 5 and $30 \mathrm{kDa}$ membranes and 5 $\mathrm{mM}$ for the $15 \mathrm{kDa}$ membrane. 


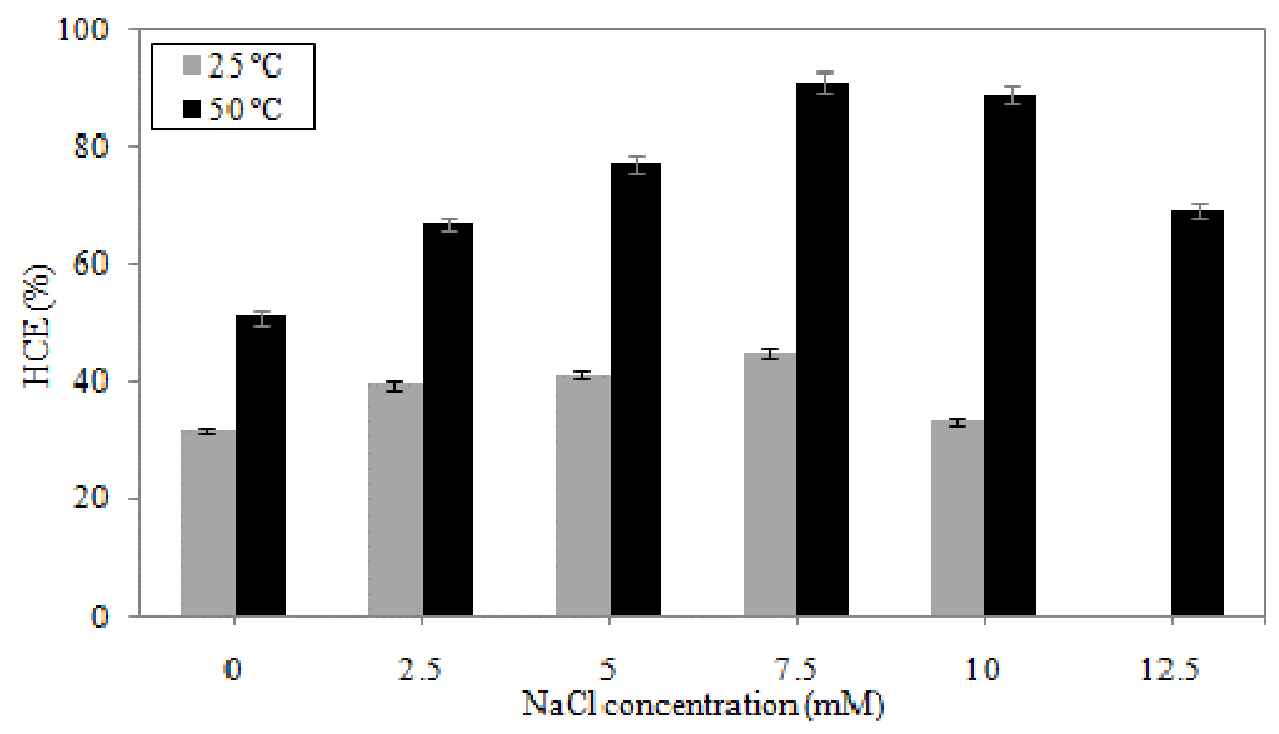

(a)

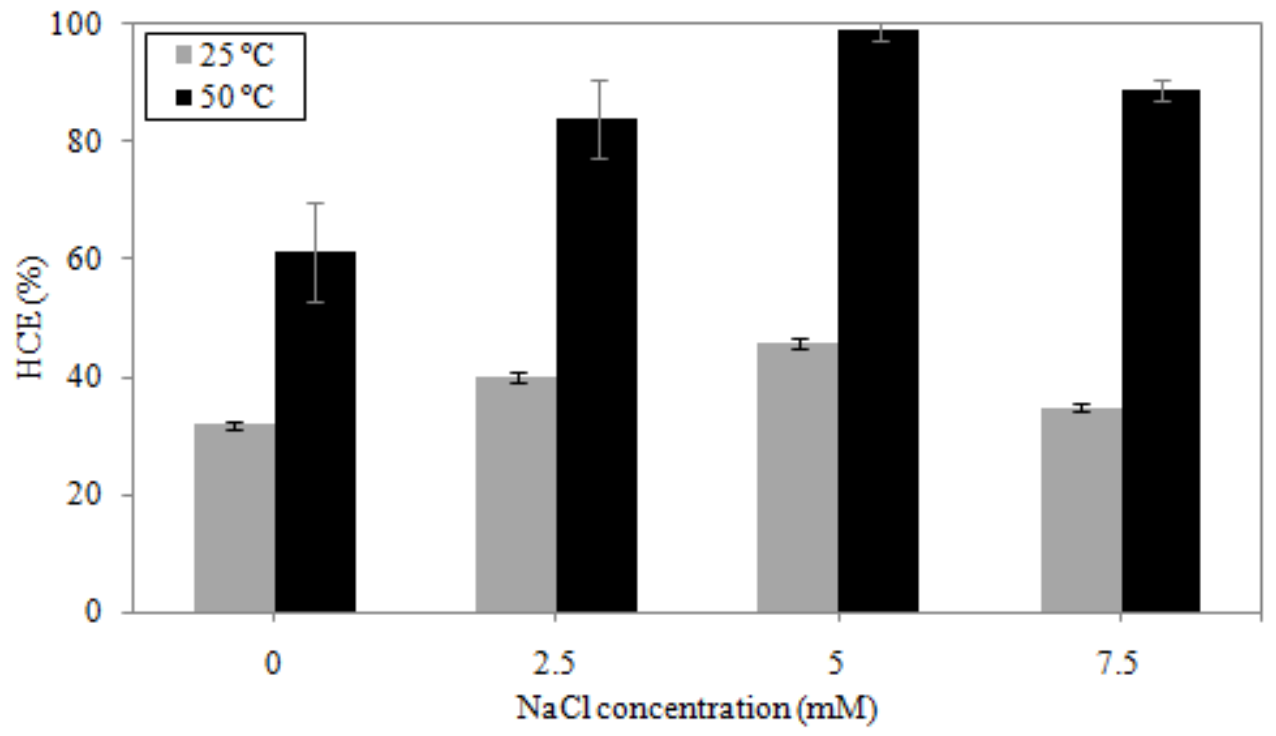

(b)

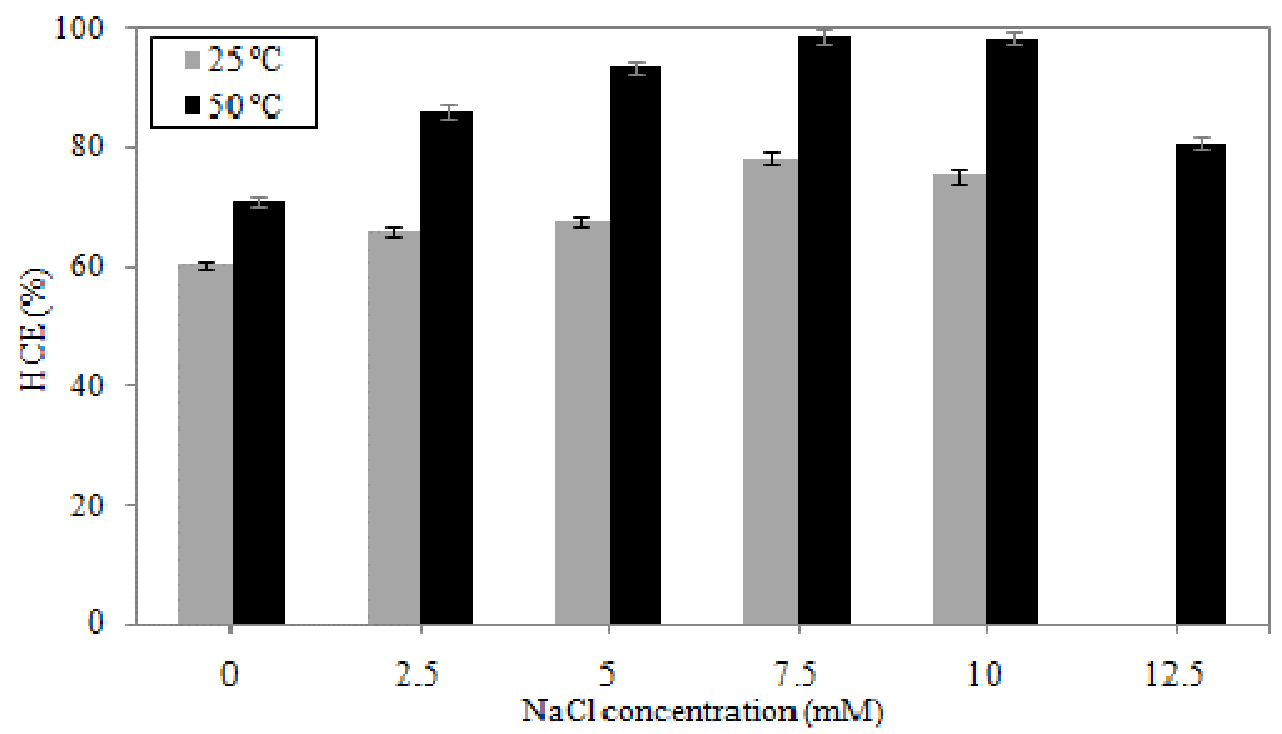

(c)

Fig. 4. Influence of $\mathrm{NaCl}$ concentration on the values of $\mathrm{HCE}$ for the membranes of $5 \mathrm{kDa}(\mathrm{a})$, $15 \mathrm{kDa}(\mathrm{b})$ and $30 \mathrm{kDa}(\mathrm{c})$, when the cleaning solution temperature is $25^{\circ} \mathrm{C}$ (grey bars) and 50 ${ }^{\circ} \mathrm{C}$ (black bars) and the crossflow velocity is $2.18 \mathrm{~m} \cdot \mathrm{s}^{-1}$ for the polymeric membranes and 4.2 $\mathrm{m} \cdot \mathrm{s}^{-1}$ for the ceramic membrane. 


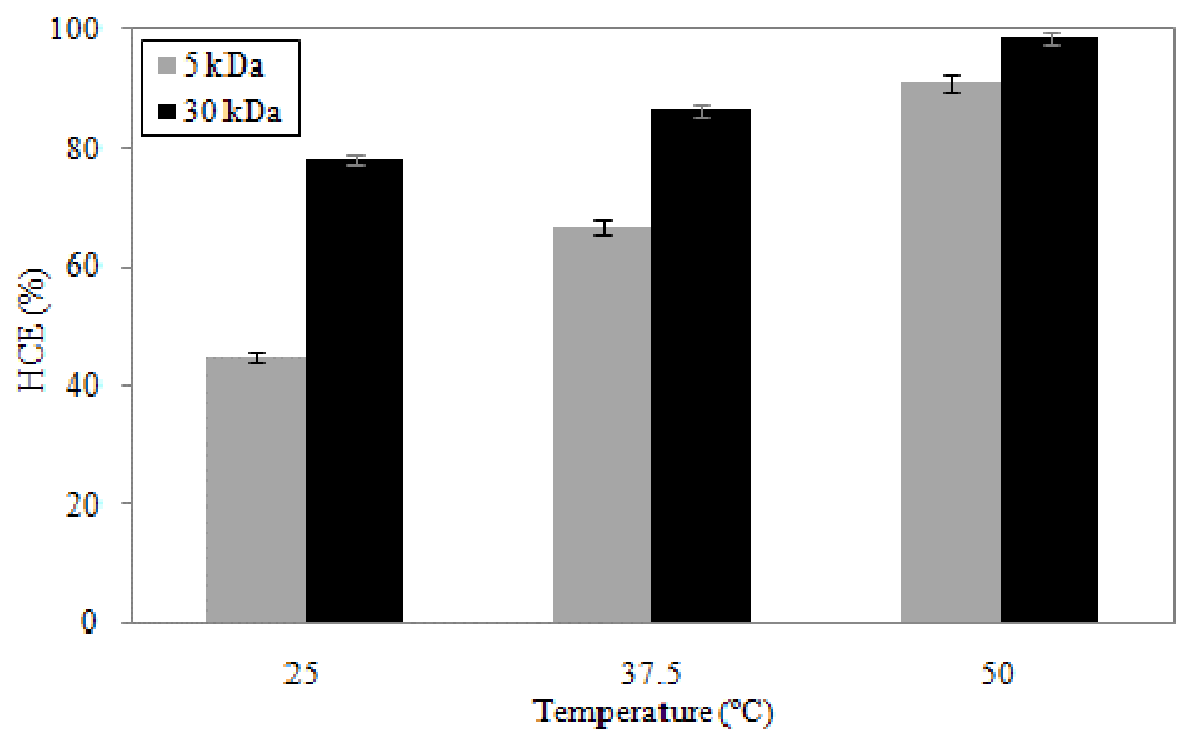

(a)

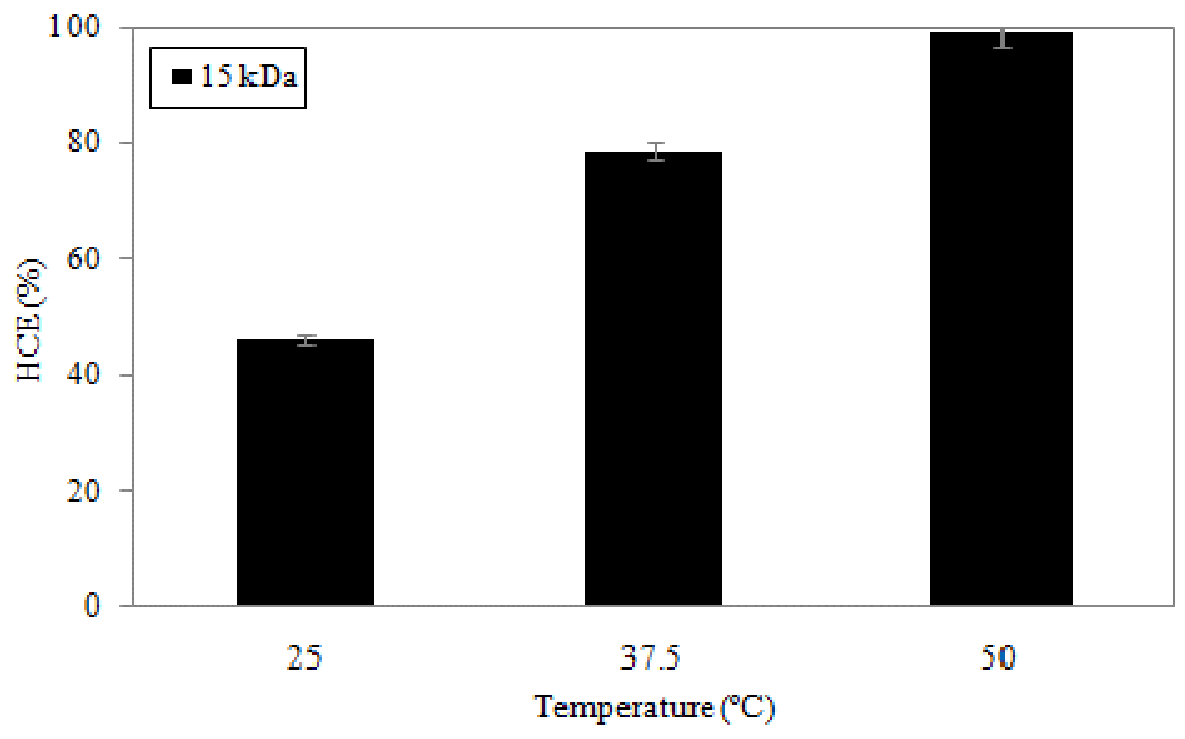

(b)

Fig. 5. Influence of temperature on the values of $\mathrm{HCE}$ for the membranes of: (a) $5 \mathrm{kDa}$ (grey bars) and $30 \mathrm{kDa}$ (black bars) at $2.18 \mathrm{~m} \cdot \mathrm{s}^{-1}$ and a $\mathrm{NaCl}$ concentration of $7.5 \mathrm{mM}$, and (b) 15 $\mathrm{kDa}$ at $4.2 \mathrm{~m} \cdot \mathrm{s}^{-1}$ and a $\mathrm{NaCl}$ concentration of $5 \mathrm{mM}$. 


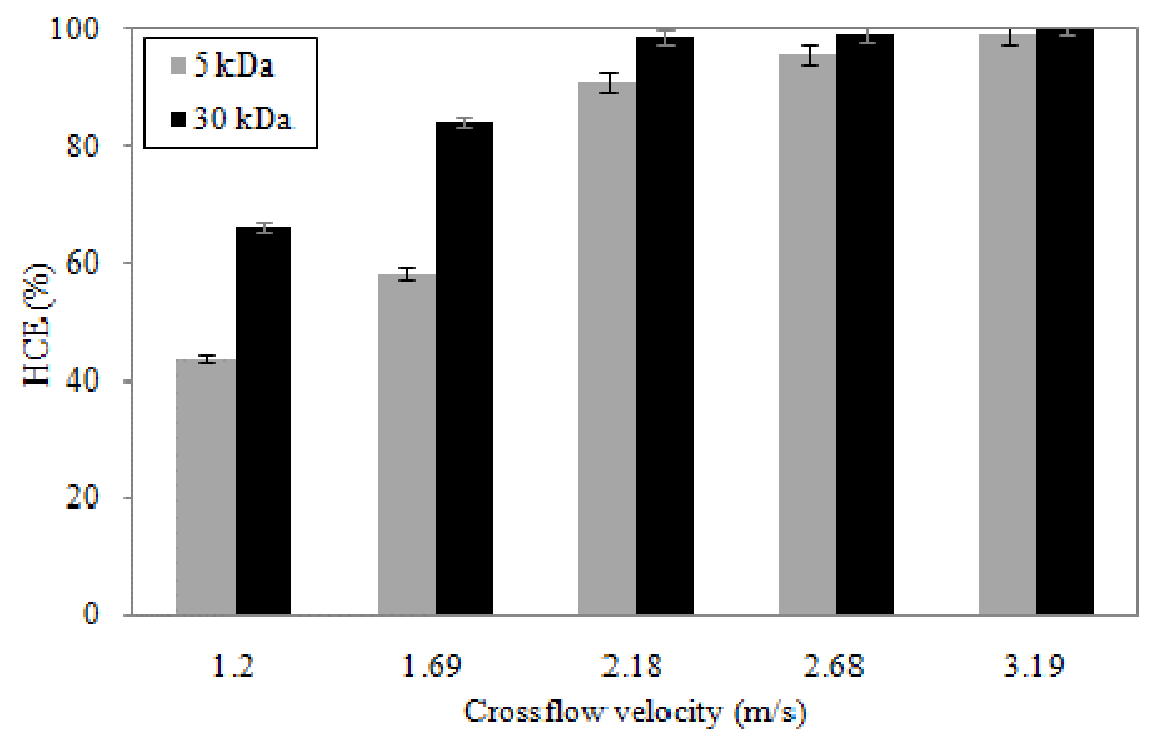

(a)

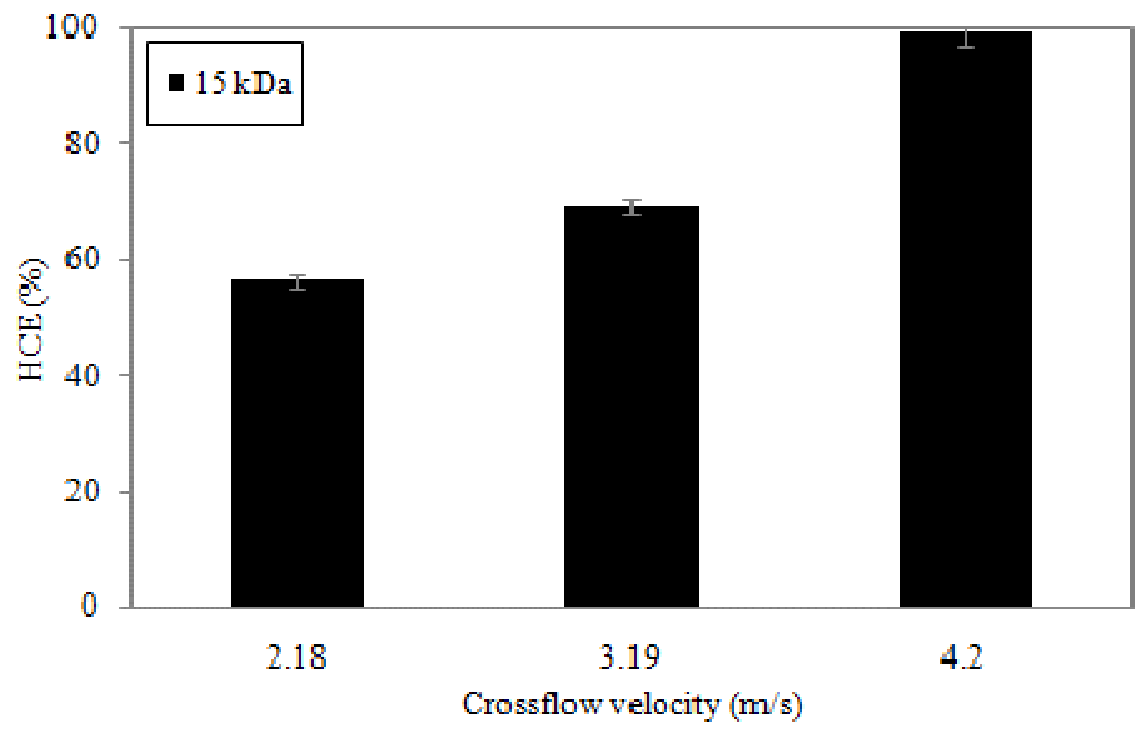

(b)

Fig. 6. Influence of crossflow velocity on the values of HCE for the membranes of: (a) $5 \mathrm{kDa}$ (grey bars) and $30 \mathrm{kDa}$ (black bars) at $50{ }^{\circ} \mathrm{C}$ and a $\mathrm{NaCl}$ concentration of $7.5 \mathrm{mM}$, and (b) 15 $\mathrm{kDa}$ at $50^{\circ} \mathrm{C}$ and a $\mathrm{NaCl}$ concentration of $5 \mathrm{mM}$. 

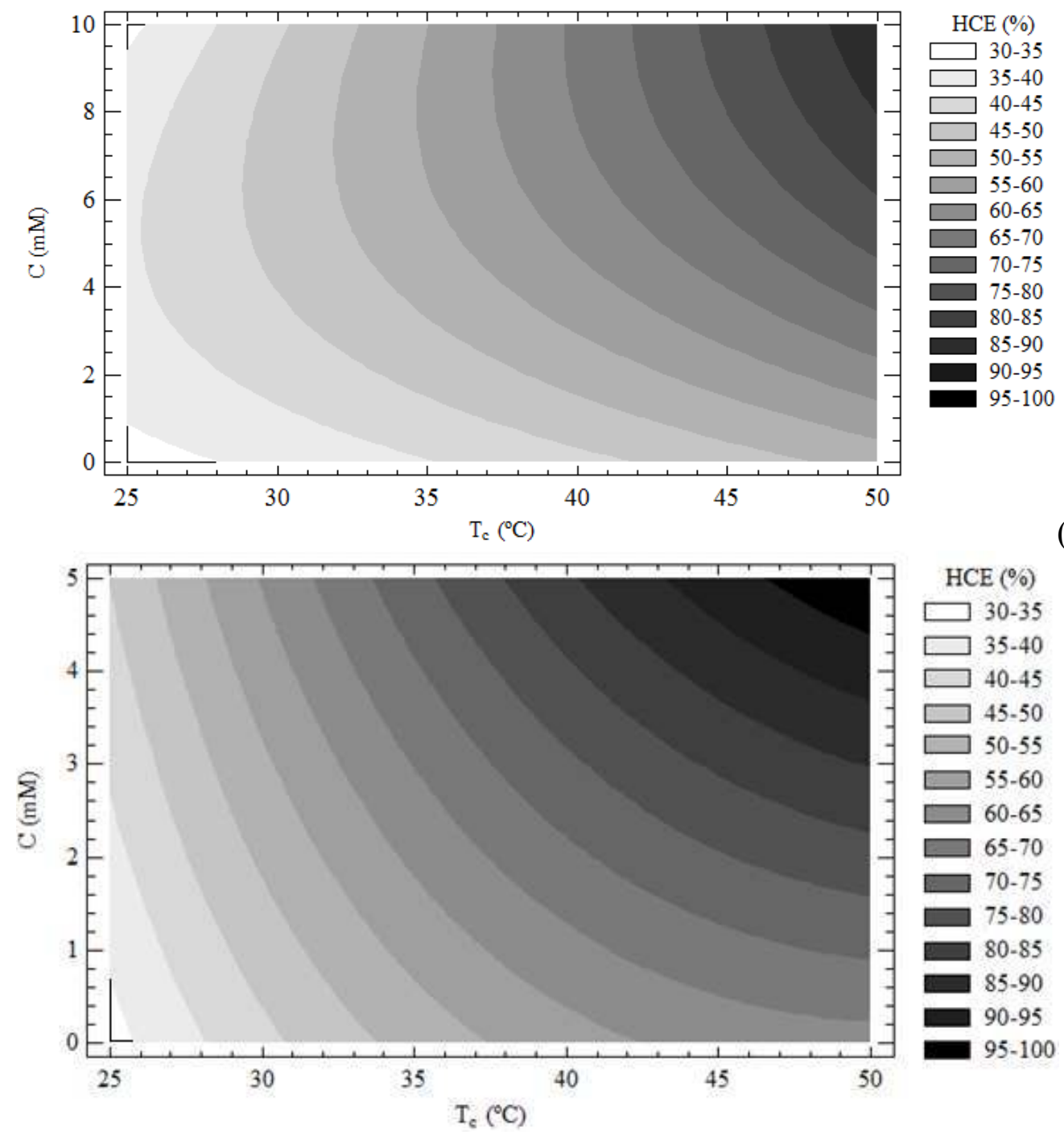

HCE $(\%)$

(a)

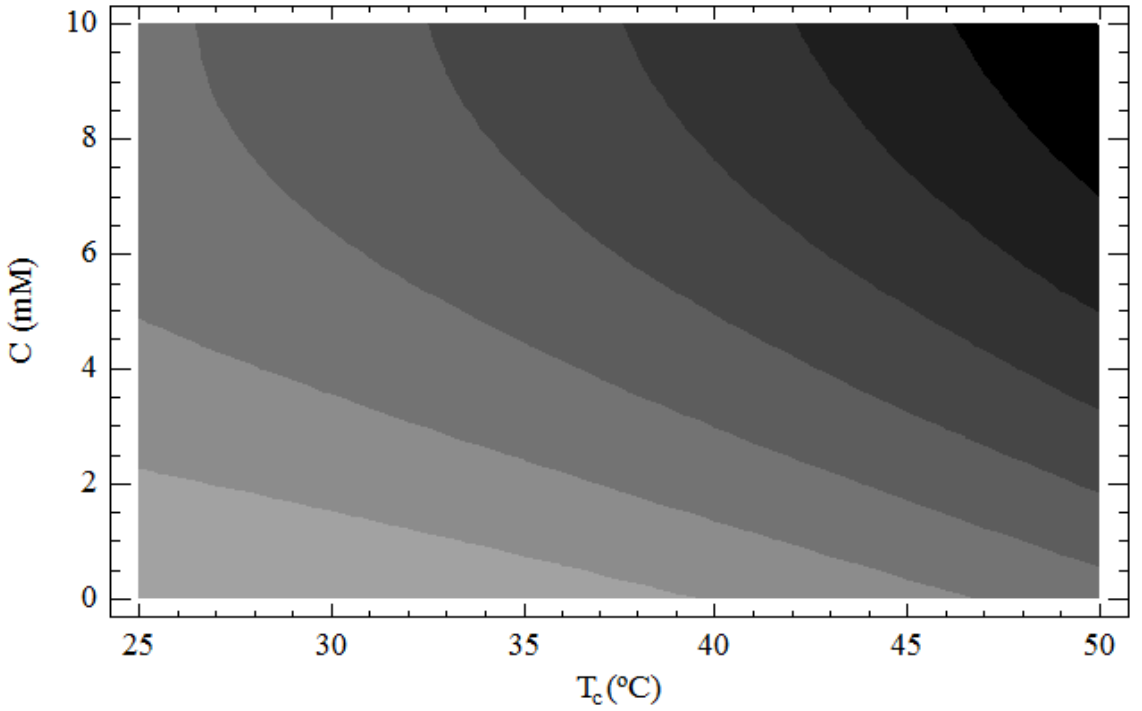

(b)

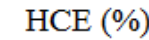

65-70

70-75

75-80

80-85

85-90

90-95

95-100

(c)

Fig. 7. Contour plot for $\mathrm{HCE}$ as a function of temperature and $\mathrm{NaCl}$ concentration for the membranes of $5 \mathrm{kDa}(\mathrm{a}), 15 \mathrm{kDa}(\mathrm{b})$ and $30 \mathrm{kDa}$ (c) at a crossflow velocity of $2.18 \mathrm{~m} \cdot \mathrm{s}^{-1}$ for the polymeric membranes and $4.2 \mathrm{~m} \cdot \mathrm{s}^{-1}$ for the ceramic membrane. 
Table 1

Main properties of the membranes used.

\begin{tabular}{lccc}
\hline Item & UP005 & INSIDE-CERAM & UH030 \\
\hline Manufacturer & Microdyn Nadir & TAMI Industries & Microdyn Nadir \\
Type & Flat-sheet & Tubular & Flat-sheet \\
MWCO $(\mathrm{kDa})$ & 5 & 15 & 30 \\
Active layer & $\mathrm{PES}$ & $\mathrm{ZrO}_{2}-\mathrm{TiO}_{2}$ & $\mathrm{PESH}$ \\
Effective area $\left(\mathrm{cm}^{2}\right)$ & 100.00 & 35.51 & 100.00 \\
Water permeability & 42.61 & 60.37 & 106.17 \\
$25^{\circ} \mathrm{C}\left(\mathrm{L} \cdot \mathrm{m}^{-2} \mathrm{~h}^{-1} \cdot \mathrm{bar}^{-1}\right)$ & & & \\
Maximum operating & 95 & 95 & 95 \\
temperature $\left({ }^{\circ} \mathrm{C}\right)$ & $0-14$ & $0-14$ & $0-14$ \\
pH range & & & \\
\hline
\end{tabular}

Table 2

ANOVA results for the model equations that relate HCE with the operating parameters.

\begin{tabular}{ccccc}
\hline MWCO $(\mathrm{kDa})$ & Parameter & Coefficient & Estimated value & $\mathrm{p}$-value \\
\hline \multirow{5}{*}{5} & Constant & $\mathrm{a}(\%)$ & -112.043 & 0.0000 \\
& $v$ & $\mathrm{~b}\left(\mathrm{~m}^{-1} \cdot \mathrm{s}\right)$ & 97.093 & 0.0000 \\
& $T_{c} \cdot C$ & $\mathrm{c}\left({ }^{\circ} \mathrm{C}^{-1} \cdot \mathrm{mM}^{-1}\right)$ & 0.134 & 0.0000 \\
& $T_{c}{ }^{2}$ & $\mathrm{~d}\left({ }^{\circ} \mathrm{C}^{-2}\right)$ & 0.010 & 0.0001 \\
& $C^{2}$ & $\mathrm{e}\left(\mathrm{mM}^{-2}\right)$ & -0.299 & 0.0010 \\
& $v^{2}$ & $\mathrm{f}\left(\mathrm{m}^{-2} \cdot \mathrm{s}^{2}\right)$ & -15.391 & 0.0007 \\
\hline & Constant & $\mathrm{a}(\%)$ & -43.946 & 0.0024 \\
& $T_{c}$ & $\mathrm{~g}\left({ }^{\circ} \mathrm{C}^{-1}\right)$ & 1.088 & 0.0006 \\
& $T_{c} \cdot C$ & $\mathrm{c}\left({ }^{\circ} \mathrm{C}^{-1} \cdot \mathrm{mM}^{-1}\right)$ & 0.187 & 0.0010 \\
& $C^{2}$ & $\mathrm{e}\left(\mathrm{mM}^{-2}\right)$ & -0.653 & 0.0054 \\
& $v^{2}$ & $\mathrm{f}\left(\mathrm{m}^{-2} \cdot \mathrm{s}^{2}\right)$ & 2.968 & 0.0001 \\
\hline & $\mathrm{Constant}$ & $\mathrm{a}(\%)$ & -50.809 & 0.0029 \\
& $C$ & $\mathrm{~h}\left(\mathrm{mM}^{-1}\right)$ & 4.322 & 0.0001 \\
& $v$ & $\mathrm{~b}\left(\mathrm{~m}^{-1} \cdot \mathrm{s}\right)$ & 75.194 & 0.0000 \\
& $T_{c}{ }^{2}$ & $\mathrm{~d}\left({ }^{\circ} \mathrm{C}^{-2}\right)$ & 0.011 & 0.0000 \\
& $C^{2}$ & $\mathrm{e}\left(\mathrm{mM}^{-2}\right)$ & -0.221 & 0.0095 \\
$v^{2}$ & $\mathrm{f}\left(\mathrm{m}^{-2} \cdot \mathrm{s}^{2}\right)$ & -13.333 & 0.0002 \\
\hline
\end{tabular}

Table 3

Optimal values of the operating parameters obtained by means of a pattern-search algorithm.

\begin{tabular}{cccc} 
MWCO $(\mathrm{kDa})$ & $T_{c}\left({ }^{\circ} \mathrm{C}\right)$ & $C(\mathrm{mM})$ & $v\left(\mathrm{~m} \cdot \mathrm{s}^{-1}\right)$ \\
\hline 5 & 50 & 10.00 & 3.15 \\
15 & 50 & 7.17 & 4.20 \\
30 & 50 & 9.76 & 2.82 \\
\hline
\end{tabular}

